\title{
マグネシウムクロメイトの熱分解
}

\author{
西野忠・茂木今 朝 吉・鹿野弘 \\ (武蔵工業大学) (千 葉 大 学)
}

\section{Thermal Decomposition of Magnesium Chromate}

By

Tadasi NISINO, Kesakichi MOTEKI and Hirosi SIKANO

(Musasi Institute of Technology and Faculty of Technology of Chiba University)

\begin{abstract}
A wet process for the preparation of $\mathrm{MgCrO}_{4} \cdot 7 \mathrm{H}_{2} \mathrm{O}$, which is applicable to a binder of basic refractories as an excellent substitute for $\mathrm{MgCl}_{2}$ or $\mathrm{MgSO}_{4}$, was investigated. The thermal decomposition of magnesium chromate hydrates and anhydrate was studied by using DTA, TGA and X-ray diffraction.

The following results are obtained

(1) $\mathrm{MgCrO}_{4} \cdot 7 \mathrm{H}_{2} \mathrm{O}$ is prepared by crystallization from a solution of $\mathrm{MgO}, \mathrm{Mg}(\mathrm{OH})_{2}$ or $\mathrm{MgCO}_{3}$ in chromic acid, which is thermally decomposed to give $\mathrm{MgCrO}_{4}$.

This method is preferable to a dry process which needs oxygen pressure of $12 \mathrm{~atm}$. and heating temperature of $420^{\circ} \mathrm{C}$.

(2) In dehydration of the heptahydrate, the four separate reactions distinguished in this work have been attributed to the following:

\begin{tabular}{|c|c|c|c|}
\hline $\mathrm{MgCrO}_{4} \cdot 7 \mathrm{H}_{2} \mathrm{O}$ & $=\mathrm{MgCrO}_{4} \cdot 5 \mathrm{H}_{2} \mathrm{O}+2 \mathrm{H}_{2} \mathrm{O}$ & (DTA peak temp. & $\left.33^{\circ} \& 58^{\circ}\right)$ \\
\hline $\mathrm{MgCrO}_{4} \cdot 5 \mathrm{H}_{2} \mathrm{O}$ & $=\mathrm{MgCrO}_{4} \cdot 1.5 \mathrm{H}_{2} \mathrm{O}+3.5 \mathrm{H}_{2} \mathrm{O}$ & 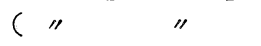 & $\left.127^{\circ} \& 150^{\circ}\right)$ \\
\hline $\mathrm{MgCrO}_{4} \cdot 1.5 \mathrm{H}_{2} \mathrm{O}$ & $=\mathrm{MgCrO}_{4} \cdot \mathrm{H}_{2} \mathrm{O}+0.5 \mathrm{H}_{2} \mathrm{O}$ & " & $\left.196^{\circ} \& 215^{\circ}\right)$ \\
\hline $\mathrm{MgCrO}_{4} \cdot \mathrm{H}_{2} \mathrm{O}$ & $=\mathrm{MgCrO}_{4}+\mathrm{H}_{2} \mathrm{O}$ & $(" \prime$ & $335^{\circ}$ \\
\hline
\end{tabular}
\end{abstract}

(3) The decomposition of $\mathrm{MgCrO}_{4}$ anhydrate begins at about $600^{\circ} \mathrm{C}$ and obeys a first-order law. The value of activation energy determined by isothermal decomposition is about $74 \mathrm{kcal} / \mathrm{mol}$.

[Received Feb. 23, 1963]

\section{I. 緒 \\ 言}

近年，製鉄，製鋼技術の急速な発展に伴い炬材は苛酷 な使用条件に耐え得るものが要望され，耐火物，補修剤 などの改良研究が行なわれている。結合剤として広く用 いられているものに硫酸マグネシウム，塩化マグネシウ ムがあるが，高温下でガス $\left(\mathrm{SO}_{2} や \mathrm{Cl}_{2}\right)$ の発生など好 ましから欢点がある・マグネシウムクロメイトはその 分解生成物が高融点を有し, 沶材組成の $\mathrm{MgO}, \mathrm{MgO}$. $\mathrm{Cr}_{2} \mathrm{O}_{3}$ を与えることから有望な結合剤と考光られる ${ }^{1)}$. マグネシウムクロメイト無水物 $\left(\mathrm{MgCrO}_{4}\right)$ の乾式合成 は $\mathrm{CaCrO}_{4}$ の場合と異なり ${ }^{2}$ 酸素分圧 12 気压, 反応温 度 $420^{\circ} \mathrm{C}$ 必要とし ${ }^{3)}$, 工業的利用の面から考元て湿式 法による合成が好ましい，湿式法で得られる $\mathrm{MgCrO}_{4}$ ・ $7 \mathrm{H}_{2} \mathrm{O}$ は $\mathrm{MgSO}_{4} \cdot 7 \mathrm{H}_{2} \mathrm{O}$ と同形で，その熱分解過程は，

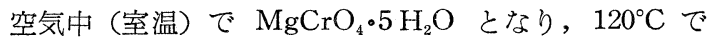
$\mathrm{MgCrO}_{4} \cdot 2 \mathrm{H}_{2} \mathrm{O}$ を与光,残余の結晶水は $\mathrm{MgCrO}_{4}$ の分 解時 $\left(650^{\circ} \mathrm{C}\right)$ 亿消失するといわれている ${ }^{3)}$. 著者らは㙁 基性炉材用結合剤としての利用研究を行なう目的で湿式 法によるマグネシウムクロメイトの合成条件を吟味し， その熱分解機構について検討した。

\section{II. 実験結果亡考察}

\section{II.1 $\mathrm{MgCrO}_{4} \cdot 5 \mathrm{H}_{2} \mathrm{O}$ の合成とその熱分解}

クロム酸溶液 $\left(\mathrm{CrO}_{3} 1\right.$ モル $\left./ 300 \mathrm{~m} l \mathrm{H}_{2} \mathrm{O}\right)$ 亿液が黄色 となるまで $\mathrm{Mg}(\mathrm{OH})_{2}, \mathrm{MgO}$ ，または $\mathrm{MgCO}_{3}$ の㲘濁 液を滴下し註 1)未反応物を濾過除去したのち濾液を濃 縮註 2)すれば，黄色澄明の棒状結晶が得られる。乙の澄 明結晶は $\mathrm{MgCrO}_{4} \cdot 7 \mathrm{H}_{2} \mathrm{O}$ (I) と考光られるが，空気中 亿放置すると漸次不澄明結晶となる。(I) を水で再結晶 (3〜4 回) 後, 常温で真空乾燥したもの (II) につい て，主に実験を行なった.（II）の化学分析結果（表-2） 加ら $\mathrm{MgCrO}_{4} \cdot 5 \mathrm{H}_{2} \mathrm{O}$ 亿相当する。

Table 1. Chemical analysis of synthetic $\mathrm{MgCrO}_{4} \cdot 5 \mathrm{H}_{2} \mathrm{O}$

\begin{tabular}{|c|c|c|c|}
\hline \multicolumn{2}{|c|}{$\begin{array}{c}\mathrm{Cr}(\text { wt. } \%) \\
\text { (Volumetric) }\end{array}$} & \multicolumn{2}{|c|}{$\begin{array}{c}\mathrm{Mg}(\mathrm{wt} . \%) \\
\text { (Gravimetric) }\end{array}$} \\
\hline Observed & Theoretical & Observed & Theoretical \\
\hline 22.58 & 22.59 & 10.57 & 10.56 \\
\hline
\end{tabular}

註 1) $\mathrm{MgCl}_{2}$ 水溶液を用いた場合のように反応液が著しく酸 性のときは, 重クロム酸塩の析出が考元られる.アンモニヤ水を 加光塩基性となし,生じた結晶を数回再結晶しても $\left(\mathrm{NH}_{4}\right)_{2} \mathrm{CrO}_{4}$ の分離は不可能であった。

註 2) 濃縮液にエチルアルコールを加えて擋拌してもよい. 
すなわち，(I) を空気中に放置したとき，不澄明にな るのは 2 分子の結晶水が失われるととに起因するものと 考えられる。いま付着水がついた状態の (I) 結晶をす ばやく粉砕し, 直ちに示差熱分析 (DTA) を行なうと $26^{\circ} \mathrm{C}$ から開始して $33^{\circ} \mathrm{C}$ にピーク温度をもつ比較的シ ヤープな吸熱と， $47^{\circ} \mathrm{C}$ に始まり約 $58^{\circ} \mathrm{C}$ にピーク温度を もつブロードな吸熱ピークが得られる。これらの吸熱現 象が前記の 初期脱水過程 $\left(\mathrm{MgCrO}_{4} \cdot 7 \mathrm{H}_{2} \mathrm{O}=\mathrm{MgCrO}_{4}\right.$ ・ $\left.5 \mathrm{H}_{2} \mathrm{O}+2 \mathrm{H}_{2} \mathrm{O}\right)$ に関係があるものと考えられるが，乙 てでは詳細には検討しないてとにする。

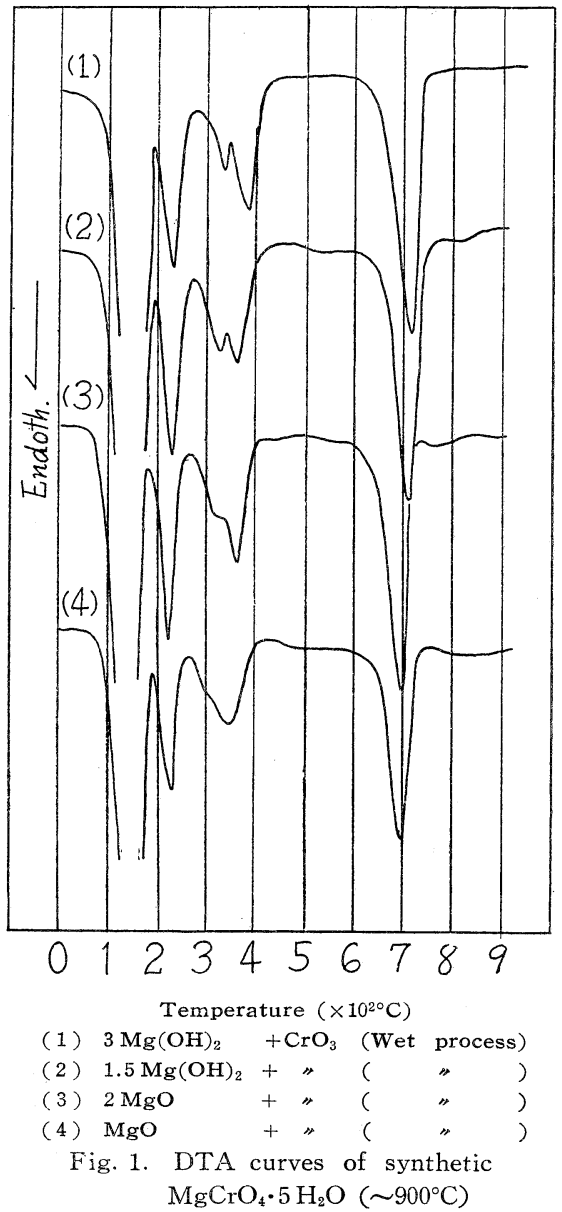

図-1 は (II) の DTA 曲線（三田村理研製， $10^{\circ} \mathrm{C} /$ min) を示す. 曲線 (1), (2) は $\mathrm{Mg}(\mathrm{OH})_{2}$ と $\mathrm{CrO}_{3}$ (モ ル比はそれぞれ $3: 1$ 及び $1.5: 1$ )，(3),(4) は $\mathrm{MgO}$ と $\mathrm{CrO}_{3}$ (モル比は $2: 1$ および 1:1）の湿式反応によ って得られたもので，いずれもほぼ類似の曲線を与え る. 表-1 から (II) が $\mathrm{MgCrO}_{4} \cdot 5 \mathrm{H}_{2} \mathrm{O}$ であるととが わかったので, 低温用 DTA 装置 (島津製 DT-10 型) を用いて脱水過程について検討した。得られた結果の一 例を図-2(1) に示す。

いま組成式が (II) と類似し，しかも脱水過程が既知 である $\mathrm{CuSO}_{4} \cdot 5 \mathrm{H}_{2} \mathrm{O}$ (図-2(2)）を基準にとって各吸熱

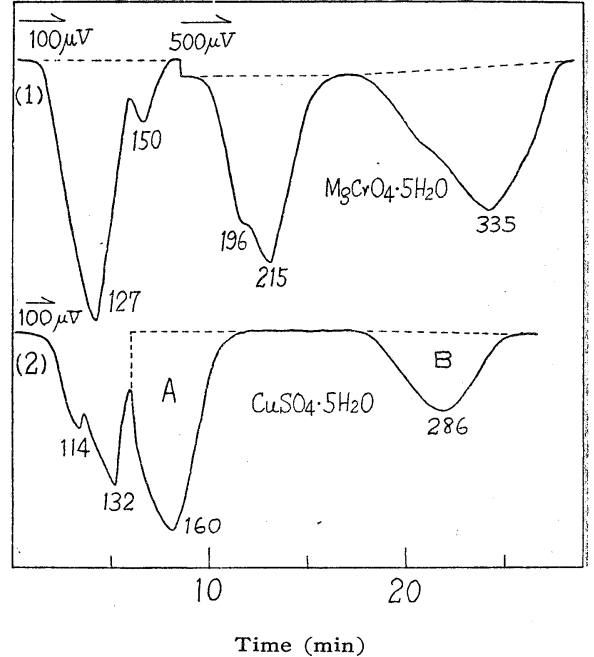

Fig. 2. DTA curves of $\mathrm{MgCrO}_{4} \cdot 5 \mathrm{H}_{2} \mathrm{O}$ and $\mathrm{CuSO}_{4} \cdot 5 \mathrm{H}_{2} \mathrm{O}\left(\sim 400^{\circ} \mathrm{C}\right)$

ピーク面積から脱水量の推定を行なった4). 図-2(2) の 比較的よく分離した吸熱ピークは, $\mathrm{CuSO}_{4} \cdot 3 \mathrm{H}_{2} \mathrm{O} \rightarrow$ $\mathrm{CuSO}_{4} \cdot \mathrm{H}_{2} \mathrm{O}(\mathrm{A})$ と, $\mathrm{CuSO}_{4} \cdot \mathrm{H}_{2} \mathrm{O} \rightarrow \mathrm{CuSO}_{4}$ (B) のそれ ぞれ 2 モルおよび 1 モルの水分子の脱出であることが知 られているが，(A) と（B）の面積比を求めると 1.95 : 1.0 で, 吸熱ピーク面積は結晶水の脱出量とほぼ比例関 係にあり, $\mathrm{MgCrO}_{4} \cdot 5 \mathrm{H}_{2} \mathrm{O}$ (II) の DTA 曲線からもそ の脱水過程が一応判定されるものと考えられる。そこで 図-2(1) の各吸熱部分の面積比を測定すると, Endo。 127，150註3)を有する部分, Endo. 196，215 を有する 部分, および Endo. 335 を有する部分の面積比は大略, 3.5: 0.5 : 1.0 となる.以上の結果から $\mathrm{MgCrO}_{4} \cdot 5 \mathrm{H}_{2} \mathrm{O}$ の脱水過程として式 (1)〜(3) が考えられる.

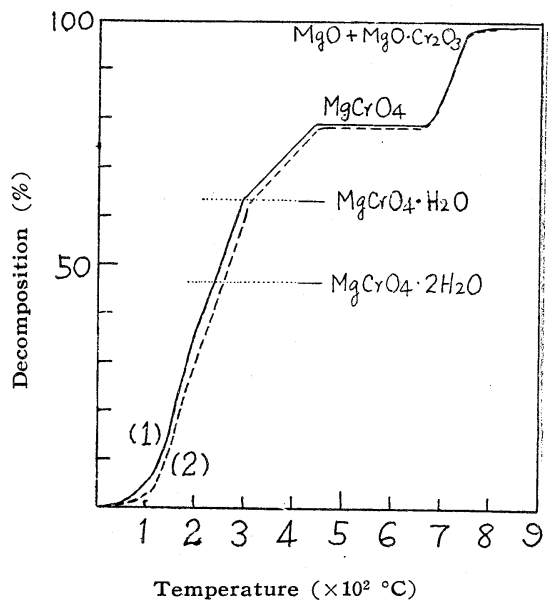

Fig. 3. TGA curves of $\mathrm{MgCrO}_{4} \cdot 5 \mathrm{H}_{2} \mathrm{O}$ $\left(2 \mathrm{MgCrO}_{4}=\mathrm{MgO}+\mathrm{MgO} \cdot \mathrm{Cr}_{2} \mathrm{O}_{3}+3 / 2 \mathrm{O}_{2}\right)$

註 3）Endo. は吸熱を表わし，数字はピーク温度を示す. 


$$
\mathrm{MgCrO}_{4} \cdot 5 \mathrm{H}_{2} \mathrm{O}=\mathrm{MgCrO}_{4} \cdot 1.5 \mathrm{H}_{2} \mathrm{O}+3.5 \mathrm{H}_{2} \mathrm{O}
$$

$\mathrm{MgCrO}_{4} \cdot 1.5 \mathrm{H}_{2} \mathrm{O}=\mathrm{MgCrO}_{4} \cdot \mathrm{H}_{2} \mathrm{O}+0.5 \mathrm{H}_{2} \mathrm{O}$

$\mathrm{MgCrO}_{4} \cdot \mathrm{H}_{2} \mathrm{O}=\mathrm{MgCrO}_{4}+\mathrm{H}_{2} \mathrm{O}$

続いて加熱減量曲線 (TGA) 亿ついて考察する . 図一 3(1)，(2) はそれぞれ 図-1(1)，(4) と同一試料で $10^{\circ} \mathrm{C} /$ min (a) の加熱速度における重量変化曲線を示す.

図-3 加ら分解が (a) $90 \sim 300^{\circ} \mathrm{C}$, (b) $300 \sim 450^{\circ} \mathrm{C}$, (c) $650 \sim 850^{\circ} \mathrm{C}$ の 3 段階に分離しているととが認めら れる。乙れらを DTA 曲線（図-1 と図-2(1)）飞対応 させると，(a) は Endo. 127，150，196，215，(b) は Endo. 335，(c) は Endo. 710 亿それぞれ相当する.い ま別に, 加熱途中の試料を空冷して直ちに検鏡すると, $500^{\circ} \mathrm{C}$ 加熱では熱時, 赤褐色を呈し冷時, 橙黄色となり 光学的異方体で外観, 色調などから $\mathrm{CaCrO}_{4}$ と酷似し $\mathrm{MgCrO}_{4}$ 無水物と考光られ，また， $900^{\circ} \mathrm{C}$ 処理試料は褐 色粉末 (光学的等方体) で, $\mathrm{MgCrO}_{4}$ の分解生成物 $\mathrm{MgO}, \mathrm{MgO} \cdot \mathrm{Cr}_{2} \mathrm{O}_{3}$ (式 (4)) と考光られ, $500^{\circ} \mathrm{C}$ まで の減量（過程 $\mathrm{a}, \mathrm{b}$ ) は結晶水の離脱のみによるものと推 察される。そして図-3 亿も示したように (b) は水分 子 1 個の放出に当り Endo. 335 のブロードな吸熱ピー クとほぼ一致し, 式 (3) が確認された。しかし, 式 (1), （2）に対応する (a) の過程では TGA 曲線からは分離 されなかった．加熱速度を遅くする方法 $\left(3^{\circ} \mathrm{C} / \mathrm{min}\right)$, 階 段式加熱法 (各温度て恒量となるまで保持し, その後階 段的に温度を高くする．温度間隔 $20^{\circ} \mathrm{C}$ ) などについて も行なったが，式 (1)，(2) 亿示す過程は分離されず再 確認は不可能であった. 表-2 は図-3 の結果から, 脱 水率 $\left(\sim 500^{\circ} \mathrm{C}\right)$ および 分解率 $\left(650 \sim 850^{\circ} \mathrm{C}\right)$ を計算し たもので 表-1 と同様, $\mathrm{MgCrO}_{4} \cdot 5 \mathrm{H}_{2} \mathrm{O}$ としての理論 值とほほ一致する。

\section{Table 2. TGA of $\mathrm{MgCrO}_{4} \cdot 5 \mathrm{H}_{2} \mathrm{O}$}

No. Sample(g) Dehydroxylation(\%)* Decomposition(\%)**

10.6709 Observed Theoretical Observed Theoretical

$\begin{array}{lllccc}1 & 0.6709 & 39.47 & 39.3 & 10.14 & 10.41 \\ 2 & 0.5472 & 39.65 & " & 10.05 & \text { " }\end{array}$

* Dehydroxylation : $\mathrm{MgCrO}_{4} \cdot 5 \mathrm{H}_{2} \mathrm{O} \rightarrow \mathrm{MgCrO}_{4}+5 \mathrm{H}_{2} \mathrm{O}$

** Decomposition : $\mathrm{MgCrO}_{4} \rightarrow 1 / 2 \mathrm{MgO}+1 / 2 \mathrm{MgO} \cdot \mathrm{Cr}_{2} \mathrm{O}_{3}+3 / 4 \mathrm{O}_{2}$

次に, $\mathrm{MgCrO}_{4} \cdot 5 \mathrm{H}_{2} \mathrm{O}$ の熱分解過程における構造変 化を図示したX線回折図について検討しよう。

図-4(1) は $\mathrm{MgCr}_{4} \mathrm{O} \cdot 5 \mathrm{H}_{2} \mathrm{O}$ 粉末のX線回折図である が，各回折線から得られた面間距離 $d$ 值は ASTM カー ド (No. 1-0243) に記載されている $\mathrm{MgCrO}_{4} \cdot 7 \mathrm{H}_{2} \mathrm{O}$ の $d$ 值とほぼ一致した。なお図中, 各回折線の上に記した （）内数字は，上記カードに記入されている回折線強度 比 $I / I_{1}$ であり, 測定回折線から推察される強度比と若干 異なっている.しかし先に述べたように $\mathrm{MgCrO}_{4} \cdot 7 \mathrm{H}_{2} \mathrm{O}$ は空気中で不安定な化合物であり, 特にてれを微粉砕

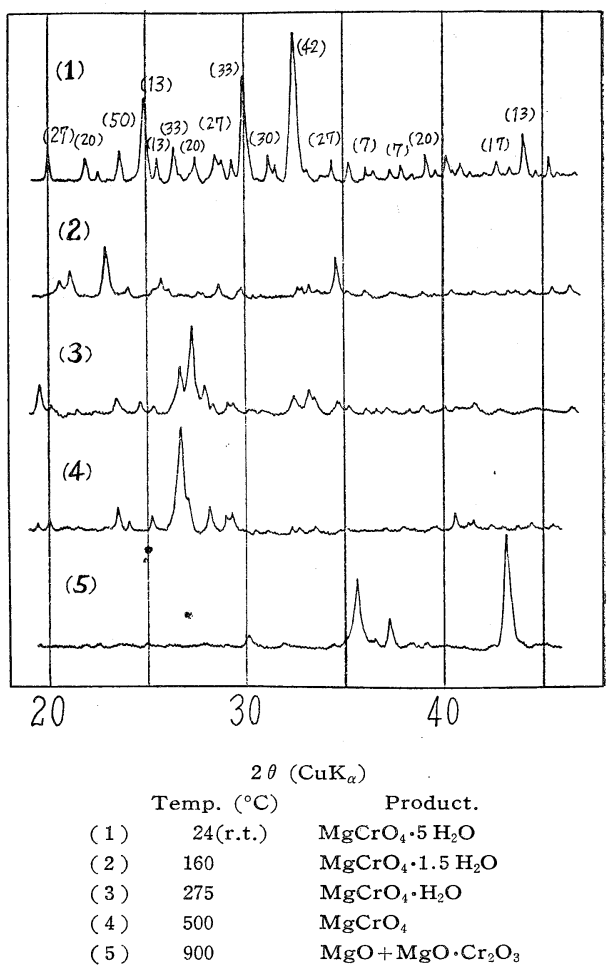

The figures cited in Fig. 4-1 are the intensity of $\mathrm{MgCrO}_{4} \cdot 7 \mathrm{H}_{2} \mathrm{O}$ (ASTM No. 1-0243) which has almost the same spacings with $\mathrm{MgCrO}_{4} \cdot 5 \mathrm{H}_{2} \mathrm{O}$

Fig. 4. $\mathrm{MgCrO}_{4} \cdot 5 \mathrm{H}_{2} \mathrm{O}$ after heating

してX線回折計にセットする間には，ほとんぞ $\mathrm{MgCrO}_{4}$ ・ $5 \mathrm{H}_{2} \mathrm{O}$ となるものと考光られ結局, 上記 ASTM カー ド記載の数值は $\mathrm{MgCrO}_{4} \cdot 7 \mathrm{H}_{2} \mathrm{O}$ でなく $\mathrm{MgCrO}_{4} \cdot 5 \mathrm{H}_{2} \mathrm{O}$ 亿相当するものと解釉される. 図-4 (2) （5）の略図は $\mathrm{MgCrO}_{4} \cdot 5 \mathrm{H}_{2} \mathrm{O}$ を $160^{\circ} \mathrm{C}$ (2), $275^{\circ} \mathrm{C}$ (3), $500^{\circ} \mathrm{C}$ (4). および $900^{\circ} \mathrm{C}$ (5) 亿加熱した場合のパターンで, 先述 の熱分析の結果から (2) は $\mathrm{MgCrO}_{4} \bullet 1.5 \mathrm{H}_{2} \mathrm{O}$ ，(3) は $\mathrm{MgCrO}_{4} \cdot \mathrm{H}_{2} \mathrm{O}$ ，(4) は $\mathrm{MgCrO}_{4}$, (5) は最終分解生成 物である $\mathrm{MgO}, \mathrm{MgO} \cdot \mathrm{Cr}_{2} \mathrm{O}_{3}$ の混合物にそれぞれ相当 する。なお，回折装置および条件は理学電機製 “Geigerflex”を用い銅対陰極（フィルター・ニッケル），電 圧 $30 \mathrm{kV}$, 電流 $10 \mathrm{~mA}$, 受光スリット $0.4 \mathrm{~mm}$, 時定数 4 秒，フルスケール $500 \mathrm{c} / \mathrm{s}$ である。

\section{$\mathrm{II} \cdot 2 \mathrm{MgCrO}_{4}$ の熱分解}

II.1 では $\mathrm{MgCrO}_{4} \cdot 5 \mathrm{H}_{2} \mathrm{O}$ の脱水反応過程 $\mathrm{MgCrO}_{4}$ の分解温度などについて述べたが， $\mathrm{MgCrO}_{4}$ の分解反 応は式 (4) 亿示すように分解と同時に $\mathrm{MgO}-\mathrm{Cr}_{2} \mathrm{O}_{3}$ 反 応が併発しており，炭酸塩などの単純分解反応と異な り, 興味ある反応と考えられ, また本試料を結合剤とし て使用した場合の $\mathrm{MgCrO}_{4}$ の熱分解にもとづく炉材の. 強度変化などとも関係しており, 今後の研究を進めるに あたり重要な問題と考えられるので, 精製 $\mathrm{MgCrO}_{4}$ ・ $5 \mathrm{H}_{2} \mathrm{O}$ を $300^{\circ} \mathrm{C}$ で 1 時間加熱して得た無水の $\mathrm{MgCrO}_{4}$ 
の熱分解反応を検討した。

$$
2 \mathrm{MgCrO}_{4}=\mathrm{MgO}+\mathrm{MgO} \cdot \mathrm{Cr}_{2} \mathrm{O}_{3}+3 / 2 \mathrm{O}_{2}
$$

使用した装置は前報ら)の石英スプリング式熱天秤で， 100 150 メッシュに節別された粉末試料 $0.500 \mathrm{~g} の$ $630 \sim 700^{\circ} \mathrm{C}$ (空気中) における恒温分解量を測定した。

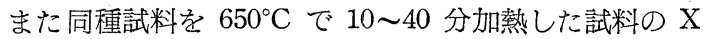
線分析も行なった。得られた結果を図-5（分解率〜時 間)，図-6 (X線分析) に示守.

いま図-5の各曲線について検討する之反応式は一次式 $d \alpha / d t=k(1-\alpha)$ (ただし $\alpha:$ 分解率， $k:$ 比例定数， $t:$ 時間) で表わされ，常法によりアレニウスプロットする と見掛けの活性化エネルギー $E \doteqdot 74 \mathrm{kcal} / \mathrm{mol}$ 㚙得られ

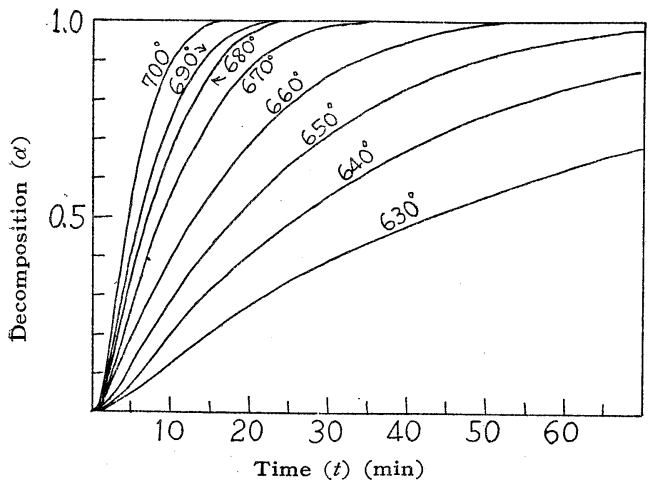

Fig. 5. The rate of decomposition of $\mathrm{MgCrO}_{4}$ at various temperatures in air

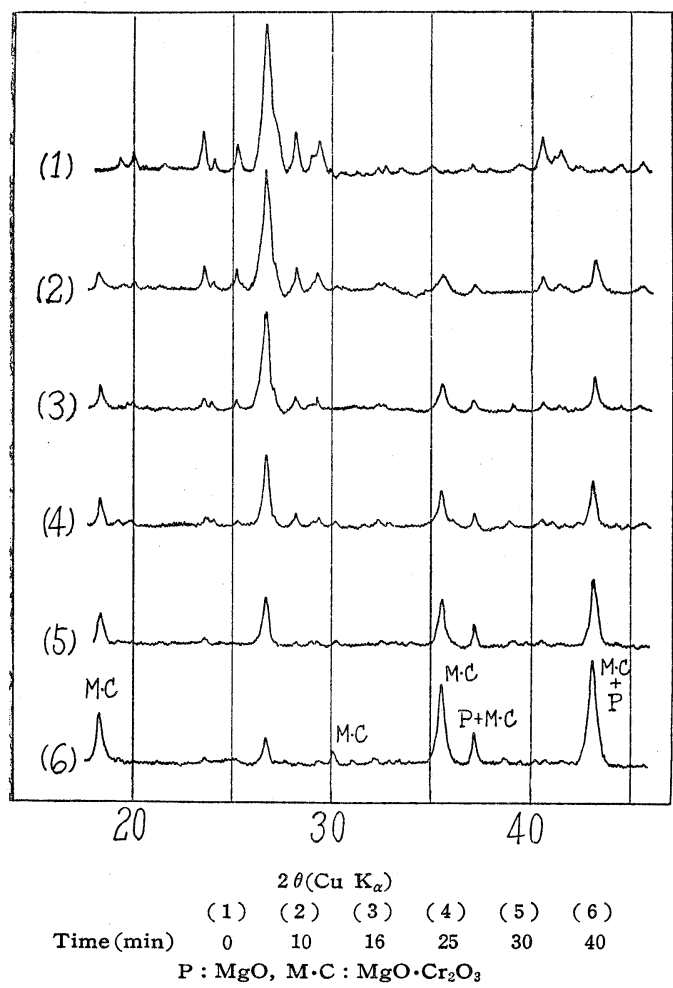

Fig. 6. X-ray patterns of $\mathrm{MgCrO}_{4}$ after heating at $650^{\circ} \mathrm{C}$ in air

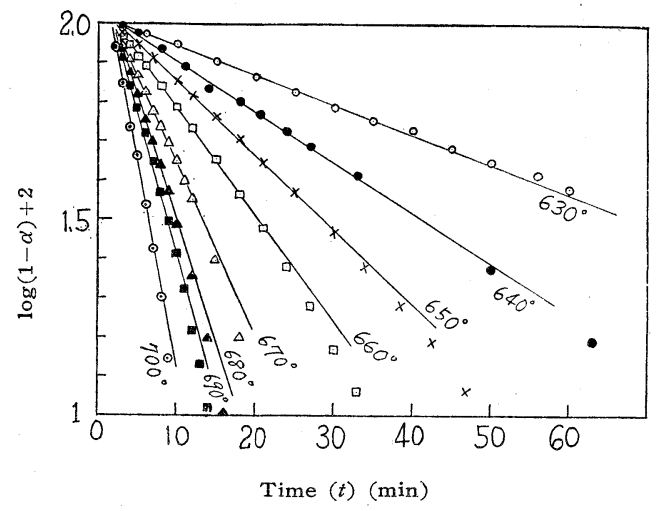

Fig. 7. $\log (1-\alpha) \sim t$

Temperature $\left({ }^{\circ} \mathrm{C}\right)$

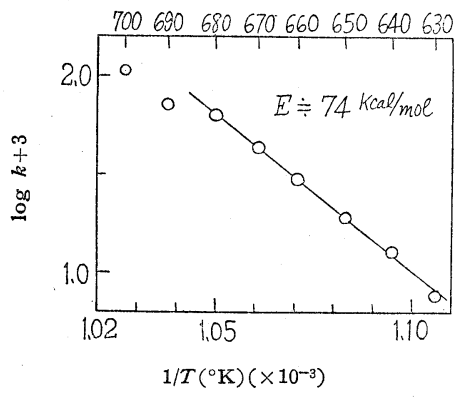

Fig. 8. $\log k \sim 1 / T$

る(図- 7,8$)$.

また，反応が一次式で示されるととから $\mathrm{MgCrO}_{4}$ の DTA を行ない昇温速度 $\phi\left({ }^{\circ} \mathrm{C} / \mathrm{min}\right)$ とピーク温度 $T m$ $\left({ }^{\circ} \mathrm{K}\right)$ の関係式 $\left.d\left(\ln \phi / T m^{2}\right) / d(1 / T m)=-E / R^{6}\right)$ 加 $E$ を求めると $78 \mathrm{kcal} / \mathrm{mol}$ が得られ, 図-8 の結果と近似 的に一致している。乙れら $E$ 值は一般の固体塩（例え ば $\mathrm{CaCO}_{3}$ など）の分解の場合に比し過大であるが，そ の理由として式 (4) に見られるように $\mathrm{MgO} \cdot \mathrm{Cr}_{2} \mathrm{O}_{3}$ の 生成反応が併行しているととが考えられる。いま $\mathrm{MgO}$ $\mathrm{Cr}_{2} \mathrm{O}_{3}$ 反応の $E$ 值 $(50 \mathrm{kcal} / \mathrm{mol})^{7)}$ を差引いた場合， 仮想される (5) 式の反応の $E$ 值が約 $24 \mathrm{kcal} / \mathrm{mol}$ とな るほぼ妥当な值と考えられる。

$$
2 \mathrm{MgCrO}_{4}=2 \mathrm{MgO}+\mathrm{Cr}_{2} \mathrm{O}_{3}+3 / 2 \mathrm{O}_{2} \cdots
$$

また定性的ではあるが，図-6 の X 線分析結果から， 加熱時間にほぼ比例して $\mathrm{MgCrO}_{4}$ の線強度が低下し， $\mathrm{MgO}, \mathrm{MgO} \cdot \mathrm{Cr}_{2} \mathrm{O}_{3}$ の線強度が増大しているととが見ら れる. 式 (4) の右行において中間生成物は存在しない ととも認められた。

\section{III. 総括}

湿式反応によりマグネシウムクロメイト水和物を合成 し，その熱分解について検討した・結果を要約すると次 の通りになる。

(1) $\mathrm{MgCrO}_{4} \cdot 7 \mathrm{H}_{2} \mathrm{O}$ は空気中に放置すると常温で 結晶水の一部を放出して $\mathrm{MgCrO}_{4} \cdot 5 \mathrm{H}_{2} \mathrm{O}$ となる。 
（2） $\mathrm{MgCrO}_{4} \cdot 5 \mathrm{H}_{2} \mathrm{O}$ は大略，次のような熱分解過 程を踏むものと考光られる。

(i) $\mathrm{MgCrO}_{4} \cdot 5 \mathrm{H}_{2} \mathrm{O}=\mathrm{MgCrO}_{4} \cdot 1.5 \mathrm{H}_{2} \mathrm{O}+3.5 \mathrm{H}_{2} \mathrm{O}$

(ii) $\mathrm{MgCrO}_{4} \cdot 1.5 \mathrm{H}_{2} \mathrm{O}=\mathrm{MgCrO}_{4} \cdot \mathrm{H}_{2} \mathrm{O}+0.5 \mathrm{H}_{2} \mathrm{O}$ $\left(168^{\circ} \sim 247^{\circ} \mathrm{C}\right)$

(iii) $\mathrm{MgCrO}_{4} \cdot \mathrm{H}_{2} \mathrm{O}=\mathrm{MgCrO}_{4}+\mathrm{H}_{2} \mathrm{O} \quad\left(260^{\circ} \sim 380^{\circ} \mathrm{C}\right)$

(iv) $2 \mathrm{MgCrO}_{4}=\mathrm{MgO}+\mathrm{MgO} \cdot \mathrm{Cr}_{2} \mathrm{O}_{3}+1.5 \mathrm{O}_{2}$ $\left(600^{\circ} \sim 740^{\circ} \mathrm{C}\right)$

これら熱分解過程におけるX線回折結果も図示した．

（3）（iv）式の反応を検討し，一次反応式で表わされ るとと，また見掛けの活性化エネルギーが $74 \mathrm{kcal} / \mathrm{mol}$ であるてとを知った。
(窯業協会東海支部, 耐火物技術協会, 石膏石灰研究会 共催の学術講演会で一部を報告した. 37.11.8)

文

1) J.C. Hicks, L.W. Austin. U.S. Pat. 2,571,134 Oct. 16 (1951)

2）西野, 茂木. 窯協, 69, 70 (1961)

3) J.W.Mellor. A comprehensive treatise on inorganic and theoretical chemistry, Vol. XI, p 274

4) G. de Josselin de Jong. J. Am. Ceram. Soc., 40, 42 (1957)

5）西野, 茂木. 工化，66，407 (1963)

6) H.E. Kissinger. J. Research Nat. Bur. Standards, 57, 212 (1956)

7) G. Parravano. J. Am. Chem. Soc., 74, 6123 (1952) (23/2/63 受付)

\title{
スラグ吸収軟化試験法による塩基性耐火物の 耐蝕性に関する一考察*
}

\author{
大庭宏・杉田清 \\ （八幡製鉄所・技術研究所）
}

\section{A Study on Slagging Resistance of Basic Refractories through Slagging-under-Load Test}

By

Hiroshi OHBA and Kiyoshi SUGITA

(Technical Research Institute, Yawata Works, Kitakyushu)

A new type of slagging test menthod for basic refractories, Slagging-under-Load Test, was proposed. follows.

The test is a kind of hot creep test with slagging. The procedure of this test is as

A columnar crucible made of specimen with the size of $50 \mathrm{~mm}$ in diameter and $50 \mathrm{~mm}$ in height and with the hole size of $20 \mathrm{~mm}$ in diameter and $30 \mathrm{~mm}$ in depth, is filled with slag powder.

The slag-filled specimen is heated at a uniform rate up to a test temperature, at which the specimen is maintained and a compressive load is applied. The rate of subsidence of specimen is measured in the similar manner to refractoriness-under-load test.

This test is based on the fact that the slagging resistance of basic refractories must be determined both by the tendency of slag penetration and by the change in refractoriness with slag absorption. Some examples of the test applied to the evaluation of basic bricks for oxygen converter and mixer lining were given.

[Received April 4, 1963]

\section{I. 緒 言}

鉄鋼精鍊窯炉を始めとする各種精錬空炉内張の耐火物 の最も重要な特性の一つは, スラグに対する抵抗性すな わち耐蝕性である. 従って, 各種精錬窯炉内張材質の選 択ないし評価は，その耐スラグ性によってほとんど決定

$*$ 昭和 36 年度化学関係学協会運合研究発表大会に挨いて一部 発表
されているのが現状である。

耐火物のスラグによる侵蝕状況を実験室的に試験する 方法は, 而火物試験法研究の最大課題の一つとして古く から試みられており, 方法の種類, 報告の数も極めて多 数にのぼっている.このことは例えば McRitchie の調 查による耐スラグ性試験法文献集 ${ }^{11}$ からもうかがわれ る。

現在までに発表された試験法の中には DIN 1069 の 